University of Rhode Island

DigitalCommons@URI

Open Access Master's Theses

1980

\title{
Environmental Mediation: A New Strategy for Environmental Conflict Resolution
}

John D. Nakagawa

University of Rhode Island

Follow this and additional works at: https://digitalcommons.uri.edu/theses

\section{Recommended Citation}

Nakagawa, John D., "Environmental Mediation: A New Strategy for Environmental Conflict Resolution" (1980). Open Access Master's Theses. Paper 611.

https://digitalcommons.uri.edu/theses/611

This Thesis is brought to you for free and open access by DigitalCommons@URI. It has been accepted for inclusion in Open Access Master's Theses by an authorized administrator of DigitalCommons@URI. For more information, please contact digitalcommons-group@uri.edu. 
ENVIRONMENTAL MEDIATION:

A NEW STRATEGY FOR ENVIRONMENTAL CONFLICT RESOLUTION

BY

JOHN D. NAKAGAWA

A THESIS PROJECT SUBMITTED IN PARTIAL FULFILLMENT OF THE REQUIREMENTS FOR THE DEGREE OF

MASTER OF CONMUNITY PLANNING

UNIVERSITY OF RHODE ISLAND

1980 


\section{MASTER OF COMMUNITY PLANNING}

THESIS PROJECT

OF

JOHN D. NAKAGAWA

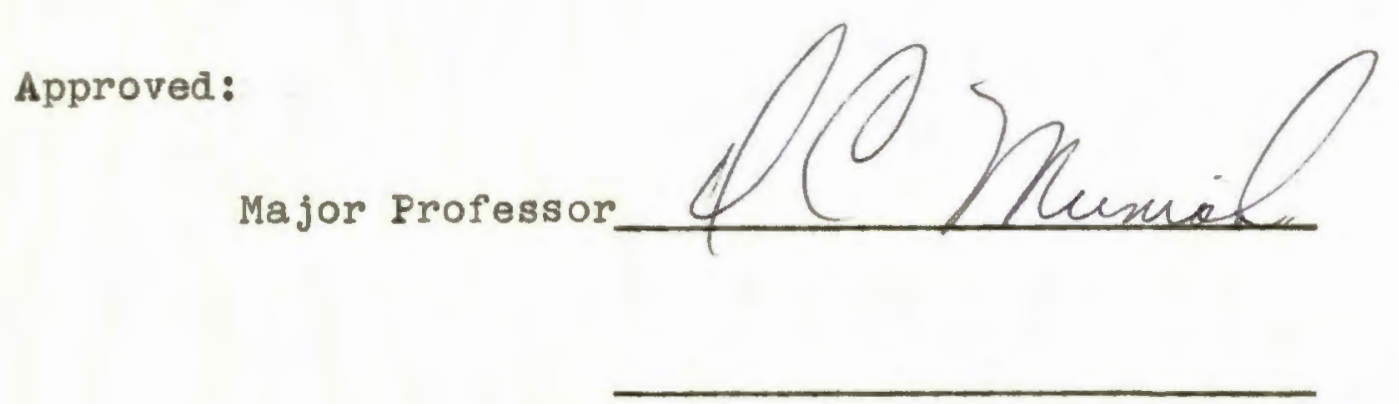

Chairman of the Graduate Curriculum in Community Planning and Area Development

University of Rhode Island 1980 


\section{PREFACE :}

The environmental movement is a product of the Seventies. With the passage of the National Environmental Policy Act (NEPA) and the first Earth Day celebration in 1970, the impetus was provided for a decade of progress in the environmental field. The movement brought on a wave of consciousness and increased awareness of our environment. It also generated a lot of controversy and conflict between the various parties involved.

Now, as we enter the Eighties the environmental movement is in trouble as a result of the conflict. Traditionally there have been three primary groups in conflict over environmental issues - the environmentalists, private industry-developer, and government. Conflicting goals, competing interest, and divergent ideologies are a few fundamental reasons for their disputes. As citizens became increasingly aware of environmental issues and concerns and their opportunities to become actively involved in the decision-making process grew, the frequency of disputes followed suit.

The present U.S. environmental protection system is largely to blame. It is based on a reactionary decision-making process established on legislation and case law. This system has created a power situation between the parties, thus fostering the conflict. Litigation has been the method for conflict resolution and decision-making. This has proven to be an undesirable method since it is so costly. With the 
litigation proliferation that has recently occurred, the courts have become bogged down and the system is faltering. Consequently the environment is the first to suffer in this situation, especially in light of the current economic state.

Obviously the system is not functionaing properly and new conflict resolution and decision-making procedures are needed. Environmental mediation is the latest method to emerge on the dispute management scene. I involves applying labormanagement mediation techniques to environmental disputes. In its limited application environmental mediation has been very successful, offering a possible alternative to litigation. The various aspects of environmental mediation will be examined and the possibilities of using it to develop a new environmental protection and management system will be explored. The thesis of this paper is that the disputing parties are responsible for maintaining a healthy environment and must therefore, resolve their conflicts and cooperatively develop, implement, and maintain a system that is satisfactory to all. 
$\underline{\text { PAGE }}$

CHAPTER ONE: INTRODUCTION AND BACKGROUND

CHAPTER TWO: AN HISTORICAL PERSPECTIVE 9

The National Environmental Policy Act 9 and the Courts

The Need For New Conflict Resolution Procedures 12

Labor-Management Roots 12

Mediation Philosophy and Concepts 17

Learning From Past Experiences 21

CHAPTER THREE: THE ENVIRONMENTAL MEDIATION FIELD 26

The Source of Conflict 27

Considerations on the Applicability of Mediation 31

Why Use Mediation? 31

Types of Disputes 34

Limitations to Mediation 36

CHAPTER FOUR: THE ENVIRONMENTAI NEDIATION FROCESS 40

Modifying Traditional Labor Mediation Techniques 40

The Mediator $\quad 41$

Case Studies 43

Implementing the Settlement 49

CHAPTER FIVE: ISSUES AND CONCERNS 51

CHAPTER SIX: NEW DEVELOPMENTS IN THE FIELD

CHAPTER SEVEN: A NEW ROLE FOR PLANNERS AND PLANNING 58

CHAPTER EIGHT: CONCLUSION 62

REFERENCES AND BIBLIOGRAFHY 65 
CHAPTER ONE: INTRODUCTION AND BACKGROUND

Nineteen-Eighty officially marks the tenth anniversary of the environmental movement in the United States. With the signing into law of the National Environmental Policy Act (NEPA) on January 1, 1970, "the nation's charter for protecting and improving the environment," was launched. (Carter, 1980: iii) Shortly thereafter, the first Earth Day celebration in April of 1970, sparked a new national interest and awareness in the environment. (Commoner, 1974) So, with NEPA providing citizens with a vehicle for active participation in the environmental decision-making process, and with Earth Day providing the impetus and motivation for action, citizen involvement in environmental affairs became a major force.

Significantly, it is the end of a decade characterized by progress in all areas of the environmental field. The increased consciousness and knowledge of our environment and its processes fueled the progress in developing new techniques for protecting and managing its use. These include environmental impact and technical assessment procedures, the evolution of environmental litigation, the new and open administrative processes implementing recent environmental legislation, and the increased interest in effective public participation approaches. (RESOLVE, 1978: 1) Developments such as these have come about through an evolutionary process, changing as necessary in order to suit the need. 
During the seventies, conflict became the symbol of the environmental movement and cosequently, conflict resolution became one of the movement's primary needs. This need for conflict resolution prompted the development of new environmental decision-making procedures such as those mentioned above. These new procedures all function, either directly or indirectly, to resolve environmental conflicts.

The battle has primarily been between the environmentalist, the developer, and the various levels of government, with the courtroom serving as their battlefield. Fundamental differences such as conflicting goals, competing interest, and divergent ideologies have been the primary source of their disputes. The present U.S. environmental protection system, which is based on legislation and case law, actually encourages this conflict situation. In this system litigation is the means for conflict resolution and decision-making. Take for example NEPA, the first substantive piece of environmental legislation. One of its primary intents was for its provisions to be enforced via citizen suit. Evidence of such intent is displayed by the fact that NEPA was written rather broadly and even ambiguously in certain sections and also, that a citizen suit provision was provided by Congress. (Like, 1976) Obviously Congress intended that the specifics of the Act be workded out and defined through litigation and the judicial process.

Herein lies the paradox of the situation. While Congress provided a vehicle for active citizen involvement, which in fact became the driving force behind the environmental movement, 
the vehicle needed to be fueled by conflict. This is primarily due to the fact that the environmental protection system is based on a reactionary, conflict producing, decision- 
making process. In this process the courts are the ultimate decision makers as they resolve and decide on conflicts over violations and discrepancies in the law. Citizen involvement in this process is reactionary and thus conflict producing. Environmentalists have had to take on a watchdog role enforcing violations of provisions.

The public hearing process is further evidence that the citizen involvement vehicle is not representative of a true and active public participation system, and is another source of conflict. Lawrence Susskind, Director of the Urban Studies and Planning program at M.I.T., made this point very clear at the Lincoln Institute Land Use Symposium in Cambridge, Massachusetts:

While numerous techniques for encouraging citizen participation have been developed, barriers to meaningful public involvement in local, regional, and state land use planning still abound. There are very few instances in which broad-gauged public participation has displaced professional judgement or behindthe-scenes political "power-brokering" as the ultimate source of legitimacy in land use decision-making. Most citizen involvement efforts are still cosmetic or cooptive.

$$
\text { (Susskind, 1977: i) }
$$

Collectively, all of these factors made conflict the symbol of the environmental movement.

Within recent years the number of unmanageable conflict situations has increased markedly. As a result, what once symbolized and provided the driving force of the environmental movement may now prove to be its demise. This is largely due to the current unstable economic situation which has made costly 
court battles a losing proposition for all parties involved. There are significant economic as well as social costs incurred through the litigated resolution of environmental disputes.

The present environmental protection system with its reactionary, conflict induced, decision process is largely to blame. RESOLVE, the Center for Environmental Conflict Resolution, recognizes the fact that through protracted litigation (the current situation), "enormous sums of private and public monies are expended in lobbying efforts, in legal fees, and in escalated costs of development or construction after long court-imposed delays." (RESOLVE, 1978, V) Accordingly, the environment is the first to suffer. With industry brunting these increased costs - which are ultimately passed on to the consumer - a healthy environment is being viewed as more of a luxury than a necessity as the economic situation worsens.

According to a panel of scientists speaking at a recent conference on the impact of marine pollution on society (June 23 - 25, 1980 at U.R.I.), "the environmental movement is going down the drain," as a result of the high cost of environmental protection. (Frederiksen, 1980: A-3) This means that the movement will increasingly lose public support for many environmental protection measures. As a matter of fact, this situation is currently happening as the public is being faced with a decision between a cleaner environment or increased energy supplies. For example, offshore drilling will supplement our present oil reserves but there is also the risk of oil spills. The scientists at the conference diagnosed the problem as, 
"growing public awareness of the high cost of achieving unrealistic goals." (Frederiksen, 1980: A-3) This is evidenced by recent congressional action to relax air quality standards as industry claim they cannot survive the high cost of pollution control measures. One is thus compelled to ask if industry is merely playing a political game, or are the environmentalists in fact being too unrealistic in their goals. Too, the government's present environmental protection system may be so inefficient and ineffective that they are totally to blame.

There is obviously an urgent need to develop better procedures and institutional processes for environmental protection before the environmental movement is lost in conflict. Disputes over such nationally and regionally critical issues involving energy, land use, the environment, and socio-economic progress are becoming an increasing threat to the movement as the state of the economy declines.

Fortunately not all of the conflict has been detrimental. During the past decade conflict served to spur-on and mature the environmental movement. Issues and goals were defined, and many provisions of the major environmental acts have been clarified as a direct result of conflict. Conflict has proven to be an element of evolutionary change and progress, as evidenced by the development of new decision-making procedures. Thus, in small and proper doses conflict can be productive, offering creative solutions to problems. The decision-making procedures mentioned earlier - environmental impact and tech- 
nological assessment, the evolution of environmental litigation, the new and open administrative processes implementing recent environmental legislation, and the increased interest in effective public participation approaches - are all examples of this.

According to RESOLVE, none of these procedures actually offer the "perfect" means for achieving "correct" or universally acceptable decisions. (RESOLVE, 1978: 1) But then again, in a value-laden field like environmental protection, true answers are elusive and conflicts are unavoldable. In other words, conflict-free decision-making is an ideal goal, perhaps unattainable and elusive, but nonetheless providing the necessary impetus for developing new procedures and maintaining evolutionary progress.

The development of new decision-making procedures to resolve conflicts represents an evolutionary trend towards a more sophisticated level of environmental protection and management. The most recent addition to the array of decision-making tools evolving out of the past decade is environmental mediation. Environmental mediation is similar to other forms of mediation in that a neutral intermediary is involved to facilitate decision-making and aid in conflict resolution.

Environmental dispute management is currently a rapidly developing field with continusously changing parameters. Since environmental mediation is still in its infancy, emerging just a few years ago, no universally accetable definition has been adopted yet. There seems to be as many defintions as there are 
practitioners.

Gerald Cormick, Director of the Office of Environmental Mediation at the University of Washington's Institute for Environmental Studies and one of the more experienced pioneers in the field, offers one definition of mediation that is referred to in much of the literature as "traditional" mediations

Mediation is a voluntary process in which those involved in a dispute explore and reconcile their differences. Operationally, mediation must only occur at a point after an impasse has been reached. The mediator has no authority to impose a settlement. $\mathrm{His}$ or her strength lies in the ability to assist the parties in resolving their own differences. The mediated dispute is settled when the parties themselves reach what they consider to be a workable solution.

(Cormick and Patton, 1977: 14)

Current environmental mediation practices have their roots in the labor-management negotiation model. The environmental mediation process does not carry through to the arbitration stage, however, Unlike arbitration, in which an appointed arbitrator makes a decision that the parties have agreed in advance will be binding on them, mediation achieves settlement through joint problem solving.

Environmental mediation too, may be an imperfect tool. But it is another evolutionary and progressive step away from costly court resolved conflict. Whether or not it offers an effective alternative can only be determined through trial and experience. As a matter of fact, trial and experience with environmental mediation in various situations thus far, 
has resulted in the more recent development of mediation related conflict resolution techniques.

At a conference on environmental mediation in January 1978 (co-sponsored by RESOLVE, the Aspen Institute, and the Sierra Club Foundation), participants were, "virtually unanimous in their view that this new approach to conflict resolution offers enough promise to justify rigorous efforts to apply it to environmental disputes." (RESOLVE, 1978: 1) This is not to say that environmental mediation is without problems. It does have its limitations and it is not a panacea for all conflict. The premise of this paper is that the three major conflicting groups - environmental, private industry-developer, and government - are collectively responsible for maintaing a safe, healthy, and comfortable environment in which to live. They are responsible because individually and collectively their actions have the greatest impact upon the environment. Although, a healthy environment is not a constitutional right, it is a basic human right - a necessity for survival and not a luxury. Through proper environmental management, based on cooperative responsibility and effort, all parties involved can benefit. Ideally a new environmental management and protection system should be cooperatively and collectively developed, implemented, and maintained by all affected parties.

Hence, the intent of this paper is to investigate the various aspects of environmental mediation and to explore the possibilities of applying it to developing a new system of environmental protection and management as described above. 
CHAPTER TWO: AN HISTORICAL PERSPECTIVE

THE NATIONAL ENVIRONMENTAL POLICY ACT (NEPA) AND THE COURTS:

Charles Warren, Chairman of the Council on Environmental Quality, used the phrase, "rush to the courts" in describing the American way of dealing with environmental disputes. (Warren, 1978: 9) One of the principal causes for this environmental litigation explosion was the enactment of the National Environmental Policy Act (NEPA) in January of 1970. Through NEPA and the other major environmental statutes, citizens have gained the right to use the litigation process (court suits and administrative agency proceedings) to challenge and effect adminstrative decisions of federal agencies. The intended purpose of this right is to allow citizens to participate more effectively in major governmental and corporate decision-making processes. (Like, 1976) However, the effectiveness of this intent has been questionable.

NEPA was written rather broadly with only general provisions. Consequently, the courts have been left with the task of interpreting and defining many of these ambiguous provisions. The Act simply and broadly declared it a national policy to protect and enhance the environment. (Shaw, 1976: 107)

The principal action-forcing provision of NEPA is its requirement of the preparation and publication of a statement assessing the environmental impacts for all, "major Federal action(s) significantly affecting the quality of the human 
environment." (Shaw, 1976: 109) Interpretation of this provision has been the major source of litigation. Subsequent court decisions concerning NEPA have provided citizens with a substantial base from which to take action. Irving Like, an environmental lawyer, indicates just how substantial this base is:

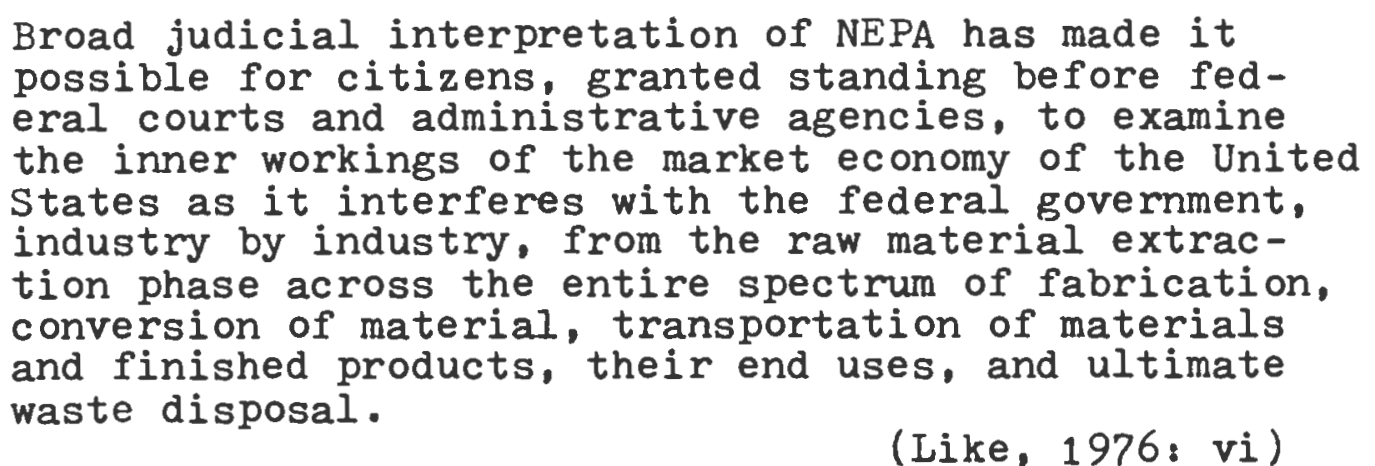

Hence, NEPA - via the courts - has been instrumental in broadening the basis for citizen intervention. For example, take the issue of standing - the legal right to bring a challenge to court. At one time standing was practically a sacred right. But now it is granted to persons with little or no economic interest as long as they can demonstrate a public concern to bring suit and to intervene in the federal courts. (Sierra Club v. Morton, 405 U.S.727.92S.Ct.1361,1972 - Shaw, 1976, : 140-141)

Although NEPA broadened the citizen intervention base, the initial provision for action was provided by the 1946 Administrative Procedure Act (5 U.S.C. Sec.701). (Shaw, 1976: 165) It came into full use by citizens in the mid-1960's as a tool for intervention into the decision-making process. 
Under this act citizens can participate in scientific evidentiary hearings of either a rule-making or an adjudicatory nature.

The number of NEPA cases coming before the courts thus far is quite large. There are also many cases being litigated under other environmental statutes as well. This time consuming and costly dispute resolution procedure is reaching proportions whereby its decision-making value is being lost. Instead of facilitating decision-making, the court process is being bogged down by delays.

The litigation explosion is affecting more than the environmental protection system. Shirley M. Hufstedler, federal judge of the Ninth Circuit Court of Appeals, Los Angeles, expressed concern over the American tendency to turn all our troubles over to the courts. In an article entitled, "What The Courts Cannot Do," appearing in the Washington Post, Judge Hufstedler points out that, "Americans have always had a litigation nabit." (Hufstedler, 1978: B-8) We appear, she wrote,

To have unbounded faith that judicial systems can supply a hope chest for every hope and a remedy for every wrong. We now expect courts to end racial tensions, sweep contaminants from the globe, and bring about an armistice in the battle of the sexes. We expect courts to assure us of a right to be born and a right to die.

$$
\text { (Hufstedler, 1978:B-8) }
$$

Such unbounded faith in the courts has created problems, as she further points out: 
We are dismayed to discover that overwhelmed courts cannot hear out complaints for months and even years, that the litigious path to justice is exceedingly costly, and that our problems do not vanish upon the issuance of a court decree.

(Hufstedler, 1978: B-8)

THE NEED FOR NEW CONFLICT RESOLUTION PROCEDURES:

The need for new environmental conflict resolution procedures has increased proportionately with the numbers of environmental dispute cases coming before the courts. RESOLVE has assessed the problem as such: "Over the past decade, as public perception of environmental problems has been matched by public opportunities to affect environmental policies, the number of environmental disputes has grown dramatically." (RESOLVE, 1978: 1) Consequently, the increased need has driven the disputants to seek alternatives and to make the necessary changes within the environmental protection system.

The environmental movement took another step forward in the evolutionary trend towards the idealistic, conflict-free environmental protection and decision-making system with the application of labor-management mediation principles to environmental dispute settlement. This is the latest advancement in the field. Its background is worth examining in order to gain a better perspective and basis for understanding mediation concepts as they apply to environmental situations.

\section{LABOR -MANAGENENT ROOTS :}

Prompted by the need for new conflict resolution techniques, 
the environmental movement turned to other fields for an answer. Potential alternatives were found in the labor-management field. The labor-management field is well established and has an extensive history of handling disputes. Attempts at mediating labor disputes date back to the late Nineteenth century in the U.S. and even earlier in England. However, truly effective efforts in this country date back to 1913 with the establishment of the Department of Labor and the subsequent appointment of "commissioners of conciliation." This organization was reconstituted in 1947 as the Federal Mediation and Conciliation service as it presently stands today. (Hodgson, 1971: ix)

Extensive experience with labor disputes enabled the labor-management field to establish the basic phiosophy and concepts of mediation. In fact, all of the labor dispute settlement concepts and techniques have been developed quite extensively over the years. It is beyond the scope of this paper to discuss all of the concepts and techniques in any detail, so only the basic ones will be presented here.

A survey of the literature on labor dispute settlement revealed that there are four basic techniques involved, including mediation. These are collective bargaining, factfinding, arbitration, and conciliation and mediation. Actually collective bargaining is the foundational concept from which the others are derived. Although this paper is primarily concerned with the process and concepts of mediation specifically, it is essential to view it in perspective of its relation- 
ship with the other techniques. (Naggiolo, 1971; Simkin, 1971; American Arbitration Association, 1979)

Collective Bargaining: A process whereby two or more disputing parties meet to discuss various phases of their relationship to identify the issues in dispute so that a mutually acceptable settlement can be negotiated. This is the principle objective of collective bargaining. The process is effective because the parties to the dispute meet face-toface, learn the sources of the problems at first hand, and design their own solutions. Unless an impasse develops, the disputants usually can settle their differences on their own. This generally results in a mutual commitment to the agreement and promotes a lasting settlement because there is a shared responsibility implied for having made the decisions and to abide by them. For these reasons, an agreement arrived at by successful collective bargaining (without the use of any outside assistance) is the most desirable method of dispute settlement. It is also the foundational concept from which the following techniques are derived.

Fact-Finding: This is an investigative process which is usually deployed when the diputants have reached an impasse in negotiations of collective bargaining. A neutral party is engaged to study the facts of the conflict and the positions of each party in order to define the major issues. The facts alone may provide the parties with a. solution to their differences. Otherwise they simply serve as the basis for further negotiation and a subsequent agreement. Thus, factfinding is essentially a tool for facilitating negotiations. 
Arbitration: This is a process which involves the submission of a dispute, either voluntarily by disputants' consensus or compulsory by law, to a neutral party who is empowered to render a judgement. The decision is based on the facts and evidence presented by the parties, and is handled in much the same manner as a judge would in a court case. The arbitrator's decision is final and binding upon the parties, and is enforceable in courts of law. The "forced decision" nature of arbitration often makes it the final alternative in the collective bargaining process when all else fails. Arbitration is viewed by many as a substitute for collective bargaining. Yet, practitioners believe that it is merely an extension of the collective bargaining process.

Conciliation and Mediation: Conciliation or mediation of disputes has been generally described as a voluntary process characterized by the intervention of an impartial third party in a dispute for the purpose of assisting the disputants to resolve their own differences. The mediator may be appointed by some government authority or an established intervention agency, but is not empowered to impose any solutions or sanctions upon the disputants. The ultimate goal of mediation is to assist disputants to arrive at their own agreement. Therefore, conciliation and mediation are truly extensions of collective bargaining. According to William Simkin, "mediation and voluntary arbitration are the only forms of third party intervention that are fully consistent with the basic premise of voluntary agreement-making," which is collective 
bargaining. (Simkin, 1971: 27)

Although the terms conciliation and mediation are often used interchangeably, there is an inherent, technical distinction separating the two processes. Conciliation is the more passive role. It involves bringing the disputants together in an atmosphere and under circumstances most conducive to fostering an objective discussion and settlement of the problem. Mediation on the other hand, is the more active role. It goes beyond conciliation and the "catalytic agent" stage. A mediator may interject into the discussions, making affirmative suggestions and recommendations for developing areas of possible agreement on the dispute issues. (Maggiolo, 1971: 10)

According to the literature from which the definitions were derived, the labor-management field is centered around these four basic dispute settlement techniques. (Maggiolo, 1971; Simkin, 1971; American Arbitration Association, 1979) Within recent years, these techniques have been adapted and applied to settling disputes in other fields.

Labor management dispute settlement techniques were first applied to the resolution of social conlict. More recently they have been applied to environmental conflict. Gerald Cormick who has been a pioneer in applying mediation techniqes to resolve both social and environmental disputes, offers an interesting observation on conflict occurrances

We exact a price from all new social movements. In the U.S., the labor movement, the civil rights movement, and now the environmental movement have all been required to exercise power to receive notice. (continued) 
Since their concerns ran counter to the established social patterns, such exercise of power usually took the form of diruption and delay of "business as usual." As a result, the very exercise of power, whether by marches and rallies, confrontations in public hearings and before legislative bodies, or in the courts, has tended to build animosity and mistrust between apposing forces and groups.

(Cormick, 1976: 217)

Out of the four fundamental labor dispute settlement techniques discussed previously, two of these - collective bargaining and mediation - have been cultivated more extensively for application to settling social and environmental conflicts. Arbitration techniques have been avoided due to its forced settlement and legally binding characteristics. This type of settlement is not suited to deal effectively with the dynamic nature of social and environmental affairs. Proper functioning of social systems and environmental protection systems are dependent upon a dynamic and cooperative working relationship between the parties involved. Arbitration is better suited to labor-management affairs in which working relationships are contractual and legally binding. (AAA, 1979)

MEDIATION PHILOSOPHY AND CONCEPTS:

Collective bargaining and mediation principles are well suited to handling social and environmental conflicts because they stress the voluntary, cooperative aspect of decisionmaking and facilitate the dynamic nature of these two systems. The philosophy of mediation reveals this characteristic and is important to understand since it is a vital factor in applying mediation techniques to the environmental field. 
According to Walter Maggiolo, to properly evaluate the role of mediation in the field of dispute settlement it should be assessed in light of some of the basic concepts upon which our democratic society has been founded. His description of the philosophy of mediation, as presented below, was chosen because it represents a consensus of the literature reviewed.

\section{The Philosophy of Mediation}

Our society is fundamentally a "meeting-of-minds" civilizattion. Our whole way of life is predicated on the principle that while the individual members of our society may have varying economic, political and social backgrounds and consequently divergent viewpoints, when occasion demands, they can and must subordinate and accommodate their self interest to the common good. As members of a democratic society, each individual group although starting from apparently widely divergent positions, can by the process of reasoning, utilization of the normal avenues of communication, discussion, judicious use of constructive compromise and recognition of the dignity of human ideas arrive at a "meeting-of-minds" and go down the road together toward a common objective- the overriding public welfare. Conflict is thus supplanted by cooperation.

$$
\text { (Maggio10, 1971:1) }
$$

Mediation concepts are all predicated upon this philosophy in some way. To illustrate this point, a few of the basic concepts are described below.

MEDIATION is an extension of the negotiation aspect of the collective bargaining process. Therefore, success is dependent upon the willingness of the disputants to make a' "good faith" effort to resolve their differences.

THE ULTIMATE GOAL of mediation is to assist the disputants in discussing and arriving at their own agreement. THE ESSENCE of mediation is compromise. Parties entering 
into negotiations and mediation must do so in good faith cooperation without the competitive attitude of trying to achieve all of their objectives while the other party(ies) achieve none of theirs.

THE PROCESS of negotiation and mediation is by its essence a process of power exchange. Thus, disputants must either be on equal power levels or possess the ability to exercise sanctions over one another in order to ensure successful mediation. Mediation is capable of recognizing any power constraints and discrepancies which may exist between the parties. It can then provide a forum whereby those involved can seek a means of finding a mutually acceptable course of action towards a settlement which can be interpreted as a "win" for all. In light of this, the mediation process involves a continuum of possible functions of a neutral party in the collective bargaining relationship.

THE ROLE OF THE MEDIATOR is thus strictly to serve as an impartial non-authoritarian, "third party." The mediator's primary function is to facilitate the negotiations by providing several services such as developing information and resource networks, opening communication channels, and exploring problems.

These fundamental mediation concepts were compiled from a general survey of the current literature. They all reflect the philosophy of mediation upon which they are predicated. In addition to these fundamental concepts Gerald Cormick has developed a set of mediation criteria. 
The Cormick criteria are based upon several major points: that mediation must be voluntary; that it represents a joint commitment by the disputing parties to the process of seeking a resolution; that the mediator will not impose a settlement; that the parties themselves are willing to reach a solution; that the mediator and the parties can and will ensure the implementation of a solution that is politically, physically and financially feasible. (RESOLVE, 1978: 17) There are five criteria:

(1) Mediation involves the use of "third party intervenors" who work from an impartial base. Impartiality is the key word here; there must be no conflict of interest on the mediator's part, and he (she) must not become an advocate for any viewpoint.

(2) Mediation is a decision-making process. This means that all parties must agree that their goal is to reach a decision through compromise, not to stall, to hold out for an extreme position or to settle for an alternative that is clearly unworkable.

(3) Mediation requires some relative balance of power between the several powers. Clearly, there can be no meaningful negotiations if one party holds all the cards.

(4) Mediation is appropriate when an impasse has been reached. The point of impasse tends to open the way for progress toward conflict resolution because it is the point at which the issues are defined, the parties are visible and involved, there is a sense of urgency, and the parties have come to realize they cannot achieve their aims unilaterally.

(5) Mediation will result in compromises being made. Mediation can help where there is a range of priorities, where there is a "better" answer, not just a non-negotiable "best" and "worst."

$$
\text { (RESOLVE, 1978: 17-18) }
$$


LEARNING FROM PAST EXPERIENCES:

The labor-management field has a long history in the United States. For instance, national policy defining the responsibilities for maintaining industrial peace to ensure economic welfare has its roots in the Labor Board of World War I, in the 1918 recommendations of the War Labor Conference Board, and in the National Production Act. Also, such policy is implicitly stated in the Wagner Act and the Labor Management Relations Act of 1947. (Maggiolo, 1971: 2) Yet, it was not until 1967 that the idea of applying labor-management techniques to a broader range of disputes seems to have emerged in print. (Foster, 1973: 6) The environmental dispute management field can learn from the past experiences of applying labor-management techniques to other fields.

Valuable background information concerning the application of labor-management mediation techniques to social and community conflict management field is provided by Howard Foster in a paper entitled, Urban Disputes, Mediation and the Planning Profession. Dr. Foster indicates that the initial proposal for broadening the range of application of labormanagement mediation techniques suggested the training of grass roots mediators, arbitrators, and local conflict resolution specialists. (Foster, 1973)

It is important to note that this initial proposal was made by a staff member of the American Arbitration Association (AAA). (Foster, 1973: 6) The AAA was instrumental from the initial stages of adapting and applying mediation techniques 
to resolve social and community conflicts. With vast labormanagement experience behind it, the AAA was able to take an active interest in promoting and nurturing this concept until it gained acceptance in the field.

Specific AAA activities involved setting up a Center for Dispute Settlement, and proposing a mediation training program directed toward Model Cities programs. The activity of the $A A A$ and efforts by other interested public mediators led to the establishment of the National Center for Dispute Settlement (NCDS) with assistance from the Ford Foundation. The Ford Foundation began funding the NCDS in March of 1969 and it was then placed under the auspices of the AAA. (Foster, 1973: 6-7)

Having established the background on applying labormanagement mediation techniques to social and community conflicts, let us now examine the source of the problem itself. The source of conflict appears to be inherent to our diverse American society. (Coleman, 1957) We are a conglomeration of different types of groups. Miany of these have divergent, competitive, or overlapping claims and goals.

Apparently there is a growing tendency for individuals to band together in pursuit of their common interests, organizing to increase their power through joint action. (Cormick, 1971) Examples of such groups include welfare recipients, tenants, students, consumers, and minority groups. An important aspect of this current trend is the awareness of black Americans that their race can provide a common denominator 
around which to organize. (Chalmers and Cormick, 1971) Similar activity has been extended to include other racial minorities and women. The actions being taken by these common-interest groups are reminiscient of the American Labor Movement. In fact, they are even employing many of the coercive tactics such as picketing, boycotts, sit-ins, and strikes that have proven to be successful in labor-management disputes. (Cormick, 1971:1)

Areas of social and community conflict include criminal warrant, campus disputes, civil rights, consumer disputes, police-community relations, poverty problems, prisons, and tenanant-landlord relations. (Foster, 1973: 1) The general public is probably most familiar with mediation as applied to settling disputes between public employees and government agencies, as seen in teacher strikes and sanitation strikes. However, mediators have been employed on a less formal basis to settle disputes in the other areas of social and community conflict listed above.

Despite these advancements, there are limitations on the degree to which labor-management techniques can be applied to social and community disputes. Apparently the transference of labor-management techniques has met with limited success. This is due to important fundamental differences between the two fields. Some of these differences stem from the fact that patterns of the labor-management collective bargaining relationship have become highly developed making some of its techniques specific to labor situations. (Cormick, 1971: 2) 
Gerald Cormick offers a possible explanation for the limited success encountered in transferring labor-management techniques to other fields. He has observed that the, "tendency to prescribe the labor-management analogy as a panacea for social and other community disputes may also be based, in part, on an inadequate analysis of the labor-management experience." (Cormick, 1971: 2) In light of this, Cormick suggests that three assumptions are frequently made when advocating the applicability of the collective bargaining model to community disputes. (Cormick, 1971: 3-5)

First: It is assumed that labor and management have learned to peacefully resolve their differences through the negotiations process. While the collective bargaining process has brought relative peace to American labor relations, community organizations may not be ready or interested in a negotiated resolution of conflict. They may first want to achieve at least some of their goals - uncompromised. This is important in establishing their clout and bargaining power.

Second: It is assumed that through the collective bargaining process unions and their membership have achieved full participation in the managerial decision-making process. In actuality, however, the participation of organized employees and their representatives in managerial decision-making is limited in both scope and frequency. There is some implicit consideration given to worker concerns in all decision-making out of respect (or fear) for the power they may exert through their unions. Community and environmental groups do not have 
a union equivalent and therefore, must establish

their bargaining power to gain input into their respective decision-making processes.

Third: It is assumed that collective bargaining has resulted in a reallocation of resources between labor and management. Yet, many economists question whether or not any meaningful reallocation has actually occurred as a direct result of the collective bargaing process. The resources in this case can be capital resources as in labor, or it can be decision-making power which would be more applicable to community and environmental situations.

To the extent that community groups or environmental groups assess the labor-management experience in the manner described above, they may be reluctant to enter into negotiations with established institutions until they have developed their bargaining power. Although the analogy may be imperfect, the labor relations experience has in fact been applied to community conflicts with partial success and does offer valuable insights into dealing with environmental conflicts. Examining the past experiences of labor and community dispute settlement may suggest possible routes by which environmental conflict may be resolved without litigation. The new and emerging field of environmental dispute management can learn a lot from these past experiences. 
policies, the number of environmental disputes has grown dramatically.

$$
\text { (RESOLVE, 1978: 1) }
$$

WILL MEDIATION WORK? Charles Warren, Chairman of the Council on Environmental Quality, has an appropriate answer:

I don't know . . but I am reminded in this context of advice President Franklin Roosevelt once gave an aide: "Take a method and try it," he said. "If it fails, try another. But above all, try something." Mediation looks good. I say let's try it.

(Warren, 1978: 16)

In light of these two questions, this chapter will explore the various aspects of the environmental mediation field.

THE SOURCE OF CONFLICT:

Given the present U.S. environmental protection system, it is inevitable that conflicts over a wide range of environmental issues will occur. Legislation and case law, the backbone of the system, have created a distinct power situation among all the parties involved. Traditionally these parties have included the environmentalist, private industry-developer, and government. The competition over power bases has created what has been described as a "no win" configuration for all concerned. (Cormick, 1976)

Several characteristics of the environmental protection process foster this conflict producing situation. For instance, the process tends to be time consuming and also, many opposing parties can easily establish standing in the courts. These two characteristics alone provide numerous opportunities for. 
challenges and means by which proposed projects may be delayed or halted. Unnecessary court delays constitute a "no win" configuration for all parties because of the extensive costs incurred.

In addition, national and state legislation have established elaborate and time consuming processes for assessing and reviewing environmental impacts of proposed public and private actions. Besides being complex many of these requirements are also ambiguous. Consequently, the role of the courts in this situation has been to clear up the ambiguities and to review the implementation of these procedures whose very complexity has provided substantial grounds for litigation.

Add to this the variables of competing priorities, different values, and contrasting ideologies of the various parties involved, and the chances for conflict increases. Each of the three major disputing groups - environmental, developmental, and governmental - plays a different role in the environmental protection process. Consequently, each is subject to different conflict situations. In a publication entitled Resolving Environmental Disputes, Larry Susskind provides an interesting perspective on each group's position. (Susskind, 1978)

Consider the dilemma involved with the government role in the environmental protection system. Government officials at all levels - federal, state, and local - are expected to balance public and private interests on an impartial basis. They must simultaneously protect the environment and promote economic development - two traditionally opposing interests. 
This has become more difficult as the pressure to develop energy supplies and the demand for more housing and jobs increases. Such a seemingly impossible task is further complicated by the fact that public officials are also charged with the responsibility of administering our land, water, air, and mineral resources under the watchful eyes of the opposing interests. Finally, as if the situation were not complicated enough, the concerned parties expect to participate in key facility planning, resource management, and other aspects of the environmental protection process. (Susskind, 1978: 1)

The environmental interest is usuallly represented by groups or organizations such as the Sierra Club and the Audubon Society. They are primarily concerned with the long-term impacts of proposed activities. The ecological, holistic nature of the environment is stressed in considering proposals for environmental intervention. In other words, the interrelatedness and cumulative nature of the impacts of proposed activities are emphasized. Environmentalists are "risk averse," That is, they would rather avoid any actions which introduce even the slightest chance that a catastrophic impact could occur, such as with a nuclear power facility, than accrue any of the benefits. Finally, environmental interests are not "homo-centric." They consider the needs of humankind to be only one part of the total environmental picture. (Susskind, 1978: 3)

Development groups, in contrast, have a much shorter time perspective when calculating the potential value of proposed 
activities. They tend to be much more opportunistic and less risk averse than their environmental counterparts. Interestingly, while environmentalists are predominantly concerned about costs (i.e. impacts) development interest concentrate on the benefits to be gained. For instance, developmental interests advocating the exploitation of natural resources argue that the short-term benefits, including jobs created and return on capital investment, far outweigh the long-term costs (i.e. environmental impacts). (Susskind, 1978: 4)

Environmental and developmental groups consistently find themselves in disagreement. This is primarily due to their inherent differences over time horizons, risk orientations, and even in the way they view the same problem situations and opportunities. Take the development of nuclear power for example. Developmentalists deal with problems or opportunities, depending upon the situation, incrementally in parts that can be treated independently of each other. Thus, nuclear power advocates would argue that new reactors should be built because the electric power is needed and store radioactive wastes until we have an effective method of disposal. In other words, they have separated the facility siting and construction issues from the waste disposal issues in order to avoid possible delays. Such action is contradictory to the holistic view of the environmentalists concerned about secondary and tertiary consequences of each action, especially those that appear desirable on a short-term basis. (Susskind, 1978: 4) Hence, when the divergent priorities, interests, values, and 
even the ideologies of the different parties are in competition over environmental issues, conflicts are sure to arise.

CONSIDERATIONS ON THE APPLICABILITY OF MEDIATION:

Why Use Miediation?: The fundamental concepts, principles, and underlying philosophy of mediation, as developed by the labor-management field, make it well suited for handling environmental disputes. As discussed previously, mediation is a voluntary process whereby disputants are assisted by a third party neutral in working out their own solutions in order to arrive at a mutually acceptable settlement. With arbitration, on the other hand, the third party neutral is directly responsible for settling the dispute rather than merely assisting the settlement process. The arbitrator's decision is judicial, as in a court of law, and is legally binding upon the parties. Such a forced-settlement procedure is better suited to labor dispute situations in which the parties' relationship is legally defined by contractual arrangements.

In turn, many of the definitive features of environmental disputes and the dynamic nature of the parties' relationships in the environmental field make mediation a valuable conflict resolution tool. As an example, mediation is capable of bridging political and power differences between disputants, thus, removing one hurdle to negotiations and eventual settlement. 
During the Spring of 1979, the National Park Service conducted workshops on mediation. In their workshop manual they clearly identify some of the features of environmental disputes which lend themselves to settlement by mediation. (AAA, 1979) These are summarized below to illustrate this point:

- Multiple Parties: Disputes often involve several parties from both public and private sectors. Each party possesses different, and often competing, interests, goals, and values. Also, the various parties may have different types and varying degrees of power. Hence, mediation may be less vulnerable than some other conflict resolution teehniques to power and status discrepancies among disputants.

- Multiple Issues: Multiple issues can arise out of a single dispute situation. This situation often results when the impacts of proposed actions are assessed in terms of the multiple component systems comprising the human environment. Under these circumstances, mediation can provide a forum for addressing multiple:issues and complex conflict situations which would otherwise have no framework for resolution.

- Degree of Uncertainty: A high degree of uncertainty is inherent in the environmental impact assessment and review process. This seems to stem from the future oriented nature of the process. Further complications arise from the fact that different parties will perceive potential, future environmental impacts of proposed actions differently. Mediation facilitates learning and generates new information for 
decision-makers thus, reducing the degree of uncertainty. One of the primary functions of the mediator is to ensure that the issues and the concerns of all parties are fully understood. Also, the environmental mediation process focuses on problem solving which also reduces the degree of uncertainty associated with environmental conflict.

- Level of Emotional Intensity: Environmental disputes often generate high levels of emotional intensity among the disputants. This obviously adds to the conflict, complicating the situation further. Fundamental group differences, such as divergent ideologies, is one reason that emotions can easily becomefactors in the dispute. Mediation allows individuals to develop the attitudes, and mutual respect and trust required to overcome emotional factors, clearing the way to tackle the true issues of the dispute.

Several other features indicate that the use of mediation as a possible altemative to litigation in decision-making is favorable. These are briefly summarized below:

- Mediation relies on persuasion, whereas litigation relies on compulsion.

- Mediation can be carried on in relative privacy. Litigation, on the other hand, inevitably exposes the parties and issues subjecting them to public scrutiny and possible counter-productive media coverage.

- Because mediation can accommodate more participants, and because in mediation neither issues nor participants are required to have standing, the process can represent the public interest more effectively. 
- Finally, litigation relies heavily on the past - on previously established principles and precedent. Mediation can focus on the present and the future.

Types of Disputes: A review of the available literature on environmental mediation reveals that environmental disputes are likely to fall into a few characteristically common categories. This observation was similarly made by Larry Susskind. He has identified and labeled three general environmental dispute categories. These are: (1) disagreements over the allocation of fixed resources; (2) disagreements regarding policy priorities; and (3) disagreements over environmental quality standards. (Susskind, 1978: 7-16) These categories will be used to describe the general types of environmental conflicts that have occurred and are likely to occur.

(1) Disagreements over the allocation of fixed resources. Conflicts of this type can be described as traditional or. classic. They involve issues over land use and developments affecting public resources. Most of the case studies of mediated disputes fall under this category. They most frequently involve disagreements over developments which may either preclude further public access and use of an area, or may have adverse environmental impacts upon the general area or specific resource such as a water supply.

(2) Disagreements regarding policy priorities. Generally, the tendency for conflict occurance in this area has stemmed from discrepancies over policies involving resource allocation priorities. Typical policy priority disputes have involved 
competition among the various interest groups over such matters as the allocation and use of public revenues. Policy level conflicts appear to be occurring with increasing frequency. opportunities for public pariticipation in the decision and policy-making process were increased by legislation such as the National Environmental Policy Act. (Sive, 1976)

Consequently, years of frustrating experiences has made the public more adept at the participation game to the point that they are now able to effect public policy. For instance, the various interest groups have organized their lobbying efforts so that they are now able to effect policy at the legislative level before it is even subject to the traditional public hearing process. As a matter of fact, the public hearing method of participation has proven to be unsatisfactory since it is not an acceptable form of representative government. (Susskind, 1977)

This point brings up another reason for disputes over policy priorities. Our system of representative government is not and has not always been responsive to the public's ever changing needs. (Haefele, 1973) The current trend in environmental dispute settlement indicates that policy level conflicts will continue to increase in frequency and scope. (Environmental Consensus: 1978 - 1980)

(3) Disagreements over environmental quality standards. This is an area where much of the environmental litigation has been occurring. Many of the various environmental quality standards and requirements were written ambiguously and 
consequently, have been subject to public scrutiny and court challenges. Also, disputes over standard setting arise because traditional approaches to regulation, and the administration of regulations have not worked as intended. Perhaps as the legislative trend in environmental protection and management moves away from the traditional standards-and-regulation process towards more of a policy-and-program approach, conflicts of this type will decrease. More recent environmental legislation such as the Coastal $Z$ one Management Act, which emphasizes the policy-and-program approach, are representative of this trend. (Heikoff, 1977) Under this newer approach, management rather than regulation (which tends to encourage conflict) is stressed.

Categorizing conflicts by their common characteristics, as done above, provides a better perpective of conflict sources. Because the environmental dispute management field is still young, such tools may prove to be quite beneficial. In this instance, being able to recognize sources of conflict may help in moving the field away from a reactive-resolution system to a preventative system. A preventative system is more productive since conflicts can be anticipated and avoided all together, or managed so that its creative forces can be harnessed. Larry Susskind has said that, "the real problem is hamessing the interest and energy that disagreement and debate generate." (Susskind, 1978: 1)

Limitations to Mediation: Thus far, a promising and optimistic picture has been painted for the resolution of environ- 
mental conflict by mediation. However, there are some. important limitations and drawbacks which must be considered. First of all, fundamental differences between the labormanagement model and environimental dispuite stutions prevent: the wholesale transfer of labor mediation techniques for environmental conflict resolution. Ironically some of the unique features of environmental disputes which create these differences also make mediation a desirable solution. For example, labor-management disputes usually involve. only two opposing parties, while environmental disputes often affect many parties, each with different interests at stake. The voluntary and cooperative concept of mediation makes it suitable for handing this particular feature of environmental disputes. However, the actual labor mediation procedure, which is better suited for handing dual party disputes, must first be modified for environmental dispute application. Consider these other important differences:

- Labor negotiations are usually conducted on a reguzat. cyclical basis. Such a repeating feature offers the disputants an opportunity to, "come back next year for a better deal" a prospect that makes compromise easier in the bargaining process. (RESOLVE, 1972: 2) Environmental decisions, on the other hand often result in irreversible consequences offering no occassion for later revision. This is a very critical consideration.

- Negotiated settlements in the labor field are assured of being implemented because of the legally binding labor- 
management contract relationship. With environmental dispute settlements, implementation is often solely dependent upon the good faith of the parties and thus legally unenforceable. There are methods to legally or otherwise bind parties to an environmental dispute settlement but this distracts from the dynamics of the mediation process.

- In labor dispute situations the exact nature and terms of the negotiation are often spelled out, and the issues are usually clearly defined by contractual agreement (i.e. wages and working conditions). Environmental disputants will even disagree about what factors and issues need to be negotiated. Because several parties may be involved there are often different perspectives of the problem in dispute. Also, the multi-variate nature of many environmental issues (technical, social, economic, biological, etc.) contributes to the problem.

(RESOLVE, 1978 and AAA, 1979)

Another limiting factor is the simple fact that not all environmental disputes are mediable. Those diputes which do not lend themselves to mediation have been termed "either-or" cases. (RESOLVE, 1978: 19) In these situations there is no middle ground for compromise between disputants, and litigation is the preferred course of action.

There appears to be three situations in which non-mediable disputes arise. The first situation occurs when one party is flatly opposed to a proposed action. An example of this is the case of nuclear power development. Opponents are unwilling to accept any compromises, such as a smaller facility, since 
they are opposed to any facility. The second situation results when one or more parties to the dispute seeks primarily to set a precedent or clarify the meaning of a law. Finally, a third instance of a non-mediable case is one in which delaying an action serves as a form of victory for one of the parties. (RESOLVE, 1978)

Well then, what kinds of disputes are mediable? The American Arbitration Association (AAA) identifies several kinds of disputes that are likely to lend themselves to mediation:

- Disputes that are already being negotiated by the parties themselves, i.e., disputes in which there is a demonstrated desire to work cooperatively toward settlement.

- Disputes not yet being negotiated in which there is some evidence that the parties want to talk to each other, or are talking to each other privately.

- Longstanding conflicts in which the frustration of the participants has reached an intolerable level, the conflict must be resolved, and the participants recognize the need for a new approach.

- Conflicts that lack an established appropriate forum or system for resolution.

- Conflicts subject to strong external pressures toward resolution (e.g., a development project threatened with lawsuit)

- Conflicts involving so many issues and/or parties that the need for a neutral process manager is recognized, and a mediator is requested.

- Conflicts in which the disputants clearly have common goals, but are fighting over altermative means to ends.

$$
\text { (AAA: 1979: 5-5) }
$$


CHAPTER FOUR: THE ENVIRONMENTAL NEDIATION PROCRSS

Most of the major factors dealing with the application of mediation techniques to resolving environmental conflicts have been presented and discussed. Now the actual mediation process and how it works can be examined. This will be done through a four part discussion which will provide a basic understanding of the environmental mediation process. The four topic areas include: (1) modifying traditional labor mediation techniques; (2) the mediator: (3) case studies; and (4) implementing the settlement.

MODIFYING TRADITIONAL LABOR MEDIATION TECHNIQUES:

As discussed previously, fundamental differences preclude the woholesale transfer of the labor-management mediation experience to environmental dispute resolution. Modifications to labor mediation techniques must first be made in order to suit the special characteristics of environmental conflict situations. Although specific procedural modifications must be made on a situational basis, there are a few basic conceptual changes which can be instituted across the board. Such changes would involve placing the emphasis on and encouraging the voluntary and cooperative win-for-all attitude throughout the entire negotiation-mediation process. This is essential because unlike the labor negotiations process, arbitration is not an alternative should mediation fail. Also, most of the basic labor mediation concepts can be modified to 
handle multiple parties and multiple issues encountered in environmental conflicts. Another modification would involve establishing criteria and a system for pre-screening environmental disputes to determine whether they are mediable or not.

THE MEDIATOR:

Although the mediator is "merely" a third party neutral, supposedly assisting in negotiations as though he (she) were invisible, the mediator plays an essential and integral role in the mediation process. There are three key aspects of the mediator's role - timing of the intervention, qualifications of the mediator, and the actual functions of the mediator. Appropriate timing of intervention is critical to the success of the process. In the traditional sense, conflict resolution by mediation occurs only after an impasse is reached and polarization of the diputants has developed. (Lake, 1977: 8) Gerald Cormick has learned through his experiences that determining when a conflict is "ripe" for mediation - the exact point of impasse - is critical because intervention too early or too late can render a dispute un-mediable. (Cormick, 1976)

Timing is also highly variable since numerous interdependent factors are often in play for any given situation. Timing can be partially circumstantial; that is, it may be simply a matter of when the mediator comes on the scene. Timing can also be partially discretionary, since some mediators will only intervene on disputes which have reached an impasse. (Lake, 
1977: 8) One reason is that impasse makes issue and goal identification somewhat easier. Also, the additional pressure of a deadline, imposed by an impasse may aid the negotiation process. Hence, these advantages of waiting for an impasse must be balanced against the diadvantages of increased rigidity in the parties' positions and losing the opportunity for possible conflict avoidance.

Other related conflict resolution techniques may provide help at earlier stages, and may be effective in preventing the polarization of disputants or even in avoiding conflict all together. These techniques will be discussed in Chapter Six. Because the mediation process is dependent upon such critical factors as the timing of the inervention, mediators must be highly qualified and skilled. All of the necessary qualifications for environmental mediators have not been established yet. Since the field is young, mediators are still finding areas of dispute requiring new resolution skills.

In light of this, training in basic mediation techniques and skills by recognized experts would prove to be beneficial for new mediators. (Foster, 1973) Such training would also inspire the confidence of his(her) clients. This point brings up another qualification for environmental mediators. Mediators must be able to inspire disputants' confidence in their integrity, competance, and objectivity in resolving conflicts. Also, expertise in substantive environmental matters should be a requirement because such knowledge would add to a mediator's credibility. (RESOLVE, 1978: 6) 
The specific functions of the mediator are as varied and diverse as there are different environmental dispute situations. The environmental mediator must be flexible and creative. Varied circumstances require ingenuity on the mediator's part since there are no set rules for procedures. (RESOLVE, 1978: 7) Possible functions involve the mediator as a facilitator, a communicator, and a trainer:

- Facilitator: Creating a climate of trust and inspiring a "good faith" effort among disputants to negotiate a win-forall settlement. The mediator also facilitates negotiations by keeping discussions moving, providing a forum for the clarification of multiple issues and serving as a resource expander.

- Communicator: Opening up channels of communication especially when emotional intensity is high.

- Trainer: Possibly the most important function of the mediator may be instructing the disputants on what the negotiations process is all about. A secondary function for more experienced mediators is to instruct less experienced mediators. This builds credibility, and benefits the entire field.

Laura M. Lake, an experienced environmental mediator, says that, "intervenors are not ivory-tower policy analysts but individuals who have developed skills to win the trust of feuding groups and to craft compromises." (Lake, 1977: 7)

CASE STUDIES:

Two case studies will be presented here in order to demonstrate how the mediation process actually works. The first 
case study, the Snoqualmie River Conflict, involves the construction of a major flood control dam by the U.S. Army Corps of Engineers. It was selected because it clearly illustrates what is involved in mediating a dispute over the construction of a large-scale federal public works project. This dispute is particularly interesting because it involves many parties representing different interest. The second case study takes a look at the White Flint Shopping Mall Dispute which provides a good example of a negotiated development. This dispute was selected because it involves a smaller-scale development - a neighborhood shopping mall - a project which is easy to relate to. The parties are typical of localregional level disputes.

Conflict resolution by mediation was pioneered for environmental disputes by Gerald Cormick and Jane McCarthy of the Office of Environmental Mediation at the University of Washington. The Snoqualmie River Conflict, undertaken by Cormick and McCarthy, appears to be the first formal effort to apply the mediation process to an environmental conflict.(Cormick, 1976) As a result, this case has become somewhat of a classic and is referred to consistently in most of the literature. It is summarized below as it appeared in a RESOLVE publication. (RESOLVE, 1978)

\section{The Snoqualmie River Conflict}

Contact: Gerald W. Cormick, Office of Environmental Mediation. Institute for Environmental Studies, University of Wash- 
ington, Seattle, Washington 98195.

Conflicting Parties: Coalition of environmental and citizens' groups vs. farmers and other residents of the area where a major flood control dam was proposed.

Intermediaries: Two mediators, Gerald Cormick and Jane McCarthy, from the Office of Environmental Mediation.

Other Parties Involved: The U.S. Army Corps of Engineers, the Governor of Washington, and various state and county officials.

Case Account: Farmers and other local residents of the Snoqualmie-Snohomish River Basin east of Seattle sought relief from severe flooding which damaged their crops, their land and their structures on a number of occasions, most notably in 1959. The efforts of local government led to planning for a dam on the Snoqualmie, to be built by the U.S. Army Corps of Engineers. Opposition to the dam grew, however, out of a fear that elimination of the flood danger would spur uncontrolled development of the river basin. Governor Evans supported the coalition of environmentalists who held this view when he expressed his opposition to the dam in 1972.

Gerald Cormick and Jane McCarthy of the Office of Environmental Mediation became involved in late 1973, and learned from the corps and the state that both decision-making bodies would support efforts to mediate the dispute. The Governor formally appointed Cormick and McCarthy as mediators in May 1974. Their first task was to work with persons identified through hearing records and other sources to form a core group 
of ten persons representing various positions in the dam dispute. These people became the parties to the mediation effort. Their responsibility was to keep in touch with their constituencies to ensure that the interests they represented informally would support them formally in positions they took or decisions they reached during mediation. The mediating team took the same responsibility to ensure the support of the State and the Corps of Engineers.

Initial discussions led to agreement by all parties on a number of points that facilitated subsequent negotiations. These points included the following:

- No one wanted uncontrolled sprawl development in the valley; the farmers understood the environmentalists' concern about this possibility and endorsed stringent land-use controls to prevent it.

- Continued flooding was not a realistic approach to landuse control, the environmentalists discovered; in fact, they might be blamed for damages and injuries caused by flooding if they continued to delay or prevent construction of the dam.

- Negotiations, everyone agreed, should center around this question: "How do we provide some level of flood control, ensure the continued economic viability of the farmers and the towns, and build the kind of land use plans and controls that maintain the valley as a greenbelt with broad recreational value?"

In December 1974, the core group forwarded to the Governor a package of recommendations that were to be implemented either as a total package, or not at all. The agreement provided for:

(1) A multi-purpose flood control, hydro-electric, recreation and water supply dam on the North Fork (as opposed to the originally-proposed Middle Fork site) of the Snoqualmie.

(2) A system of levees along the middle valley flood plain.

(3) The purchase of easements and development rights in the flood plain to control land development patterns. 
(4) The establishment of a basin planning council to coordinate planning in the entire river basin.

(5) The appointment of an interim committee (including members of the core mediating group, as well as other) to oversee the implementation of the agreement.

Governor Evans announced his support for the agreement. He also received endorsements from all interested organizations, representing environmentalists, farmers, citizens, and local governments in the valley. The agreement has since been implemented successfully on schedule. (RESOLVE, 1978: 36-37)

Another form of compromised settlement through mediation is to employ mitigation measures at the cost and willingness of the developer. The White Flint Shopping Nall Dispute in suburban Washington D.C., successfully mediated by Malcolm Rivkin and his associates, provides a prime example of a negotiated development. (Rivkin, 1977) The situation, in summary, was as follows:

\section{The White Flint Shopping Mall Dispute}

Contact: Malcolm D. Rivkin, Rivkin Associates, Inc. 2900 M Street N.W., Washington, D.C. 20007.

Conflicting Parties: Shopping center developer (a major department store chain) vs. surrounding neighborhood residents represented by their civic association.

Intermediaries: A professional planner (Rivkin) and an attorney, both hired by the developer.

Other Parties Involved: Local Government. 
Case Account: In the late $1960^{\circ} \mathrm{s}$, a developer proposing to build a Bloomingdale's department store in Montgomery County, Maryland, was defeated by citizen opposition to his request for a rezoning. Unwilling to abandon what appeared to be a lucrative market, the developer sought a new site in the same area.

On the second attempt, however, the developer also adopted a new strategy. Instead of trying to win the rezoning through a public relations effort backed up by a zoning lawyer, he opted to solicit citizen support through a mediation process, directed by $\mathrm{Mr}$. Rivkin and a different attorney. The result was a successful effort culminating in the opening of a much larger shopping center complex in 1977. But the critical difference was the developer's willingness to go beyond county zoning requirements in protecting nearby residents from the secondary impacts of the mall.

For example, the final agreement - spelled out in a legally binding document - provided for a review of the site-design, right down to the detail of lighting, by the local citizens' association: Other considerations included measures to prevent vehicles or shoppers from entering the adjoining residential neighborhood, an agreement on the provision of 24-hour security by the developer, and a ban on gasoline stations or drive-in restaurants.

Most important of all, however, were two final provisions. First, the developer agreed to erect a landscaped barrier that would provide total visual and physical separation between the shopping center and the adjoining houses. Secondly, he further 
agreed to compensate the owners of several adjoining houses for any loss in property values for a period of five years either by paying the difference or by buying the house outright, at the option of the owner.

Negotiations of this sort does not fall under the strict definition of "mediation" in the sense that disputants invite a third party to serve as mediator. It is interesting to note that the mediator in this case was hired by the developer. This brings up an issue of concern in the mediation field source of funding. A general concern among practitioners is that the source of funding may bias the mediator's role. However, this case shows that funding need not inevitably affect credibility.

IMPLEMENTING THE SETTLEMENT:

Implementation of mediated settlements is one area where post-negotiation problems could arise. Dealing with such problems can be a very sticky situation since monitoring and enforcing a mutually derived settlement, made on good faith, is contrary to mediation philosophy. Some mediators like Gerald Cormick are purists and believe that a mediator's role is over after settlement has been reached. It is then left up to the parties to implement the settlement on their own through the same good faith efforts by which the agreement was reached. Then there are mediators, such as Malcolm Rivkin, who believe that, "although agreements may be negotiated in good faith, they must be monitored as developments unfold." (Rivkin, 1977:21) 
If this is the case then the mediator's role is continuous and on-going. The mediator's services may be needed beyond the settlement to: design dispute systems to handle disagreements arising out of the settlement; serve as a link with resource networks; handle requests for enforcement of compliance with an agreement; and ensure an on-going working relationship with the parties. (AAA, 1979: 3-22)

As an informational note, methods for enforcing settlements and ensuring their implementation are available. These include, for example, performance bonding and legally binding contractual arrangements. (Susskind, 1978: 103-110) As an alternative to these more traditional methods the mediator could develop an implementation process as part of the agreement. (Cormick, 1976) 
CHAPTER FIVE: ISSUES AND CONCERNS

Because environmental mediation is still a relatively new and emerging field, issues and concerns are constantly being raised by its practitioners. Among the numerous issues and concerns expressed throughout the literature, there appears to be four most frequently recurring categories. These are institutional arrangements, funding sources, public accessibility, and ethical issues.

Institutional arrangements and funding sources can actually be considered as a single issue since they are interdependent. This is an area of concern which received the most attention in the literature. It is essential to the success and survival of this fledgling field. For one thing, concrete institutional and financial arrangements would certainly aid in establishing confidence and credibility in both mediators and mediation.

The number of possible institutional arrangements for environmental mediation is substantial. For instance, RESOLVE the Center for Environmental Conflict Resolution, has put together a large and varied list of institutional possibilities ranging from a network of independent mediation organizations to a federal endowment. (RESOLVE, 1978, 22) Also, the office of Environmental Mediation at the University of Washington has been considering possible means by which the mediation process can be intitutionalized within, or complimentary to, existing social structures while monitoring its status as an extraordinary 
step in resolving environmental conflict. Possibilities under consideration include locating mediation services on university campuses, i.e. neutral territory, but with established funding from government sources.

There is currently an urgent need to establish some sort of principal organization to unify and provide direction to the fast-emerging field of environmental mediation. Such an organization would ensure consistency in general policies and practices while being funded by an acceptable source. The urgency stems from the recent proliferation of mediators and wider-spread acceptance of mediation as a viable method for dispute settlement.

A recent Newsweek article reported that environmental mediation has spawned twenty nonprofit agencies and at least one private corporation devoted primarily to resolving environmental conflicts. (Friendly, 1980) This proliferation could jeopardize the success and survival of this young field. Without the unifying direction of a principal organization, too many mediators and mediation agencies could create more problems than they solve. Problems stemming from an unmanaged mediation proliferation might include the use of inconsistent and questionable practices by unqualified mediators, thereby reducing the credibility of environmental mediation. Proliferation in itself would detract from the extraordinary step that mediation provides in resolving environmental conflict.

With respect to the funding issue, Newsweek points out that as mediators have grown in influence, they have generated controversy themselves. Since most are funded by corporate 
foundations, they have become "anathema" to some environmental groups. (Friendly, 1980: 79) Any organization of mediators must have a financial basis designed to protect its reputation for integrity and impartiality. The immediate challenge then, is to find financial support that will not jeopardize the mediator's objectivity. RESOLVE suggests that, "a balanced mix of foundation, corporate, and governmental funding, perhaps channeled into a revolving fund, may represent the best approach." (RESOLVE, 1978: 6)

The public accessibility issue is another very sensitive area of concern. Environmental mediation is a direct outgrowth of the environmental movement which has led in the trend toward public participation and visibility in decision-making. This presents somewhat of a dilemma, however, because the sensitive nature of the mediation process may preclude full publicity and open negotiation sessions in some cases depending upon the particular situation. The problem of openness and full public disclosure involves more than ethical concerns and gets into legal concerns with repect to recent passage of federal and state "Sunshine Laws." This could very well be a constraint to the continued development of the environmental mediation field. Finally, ethics in mediation presents another concern. Actually, ethics in mediation is not an autonomous issue, but rather a concern that is applicable across all aspects of the mediation process. In order to maintain his(her) credibility and to uphold the integrity of the field ethical practices must be employed at all times. Ethical practices involve ensuring that all parties receive fair and adequate represen- 
tation, maintaining an unbiased and objective position, and making sure that all parties are negotiating in good faith. 
CHAPTER SIX: NEW DEVELOPMENTS IN THE FIELD

Although environmental mediation has its roots in the labor-management model, fundamental differences prevent a direct application of labor mediation techniques to environmental disputes. In light of these differences and constraints, environmental mediators have two routes by which to proceed. The first is to continue in the manner that has become somewhat traditional; that is, to modify labor-management techniques for application to environmental situations. As an alternative, the second route calls for environmental mediators to chart new ground, specific to environmental situations, in the field of dispute management. In fact, the more recent literature on environmental mediation indicates that the charting of new ground is the current trend in the field.

Some of this new ground may lie outside the boundaries of Gerald Cormick's more traditional and narrow definition of mediation, i.e. that mediation may be implemented only after impasse has occurred. There are other mediation related approaches to dispute resolution that fall under the broader, less restrictive definition - "intervention by a third party brought in to help improve decision through some structured process." (RESOLVE, 1978: 3) Several case studies and descriptive accounts indicate that practical experience to date encourages this broader view. As a matter of fact, many prominent and experienced environmental mediators attending a recent conference on environmental mediation agreed that mediation is 
not an appropriate technique to use in every dispute. (RESOLVE, 1978)

Organizations like RESOLVE (the Center for Environmental Conflict Resolution), ROMCOE (the Rocky Mountain Center on the Environment), and Rivkin Associates, Inc. have begun to chart the new ground by pioneering techniques that could be called "first cousins" to mediation. These techniques are briefly described below:

- Negotiated Development: Negotiated development has been pioneered by Malcolm Rivkin as presented in the case studies section. This offshoot of true mediation involves the bringing in of a mediator, as opposed to inviting a mediator by disputants' consensus, by the developer to facilitate the proposed development. The mediator is used to negotiate the form and character of new development with local officials and citizens. (Rivkin, 1977)

- Conflict Assessment: Conflict assessment is an effort by a third party to evaluate specific dimensions of a conflict. and offer recommendations for the purpose of moving a conflict out of a deadlock. The third party does not offer a complete solution. Rather, the assessment and recommendation provide a new perspective on the conflict from which the disputing parties can fashion a more workable solution. (Carpenter and Kennedy, 1979: 4)

- Information Exchange: Information exchange is used to improve the understanding different parties hold toward each other, for the purpose of encouraging reasonable discussion 
and, where necessary, rational bargaining. It employs a range of techniques aimed at correcting perceptions, clarifying differences, reducing fear and building trust. Information exchange may be used in both actual and potential dispute situations. (Carpenter and Kennedy, 1979: 5)

- Conflict Anticipation: Conflict anticipation seeks to identify potential disputes in communities before opposing sides are fully established and before social and economic disruption occurs. Like mediation, conflict.anticipation seeks to replace an adversary win/lose approach with alternatives which will best meet the needs of all parties. Conflict anticipation is often preferable to mediation because it enables interested parties to work together before intense fear and distrust have developed and before serious costs have been incurred. It encourages communities to identify the widest range of options for solving a problem, thereby presenting economies in terms of social, economic, physical and legal costs. (Carpenter and Kennedy, 1979, 6)

- Consensus Building: Consensus building is a dynamic process in which mediators act as neutral facilitators to establish communication among the disputants. A basis for consensus is created by obtaining an agreement among task forces representing the disputing interests. The task forces take an active role in all stages and aspects of the negotiations process. (Clark, 1977:9) 


\section{CHAPTER SEVEN: A NEW ROLE FOR PLANNERS AND PLANNING}

With the advent of environmental mediation, a new role for planners and planning in the field of environmental protection and management has emerged. Planners in general, i.e. urban planners, have four traditional roles - managers, designers, evaluators (of policies and plans), and regulators. They can maintain any one, or a combination, of these roles in order to carry out traditional planning functions such as comprehensive city planning, municipal functional planning, and land use planning. These roles and functions are changing, however. Up until the $1960^{\prime}$ 's they were prevalent in planning. Although some of the traditional roles and functions are still carried out in many localities, there is now significant diversity in the field and among planners themselves.

During the 1960's many planners took on an advocate planning role in order to represent the underrepresented. Active public participation and collective planning became more widespread. Interest groups, often led by advocate planners, were formed. One result of this increse in representation was an increase in conflict. Disputes arose among the interest groups, and between the interests groups and government. Then in the late $1960^{\circ} \mathrm{s}$ and early $1970^{\circ} \mathrm{s}$ the idea of adapting labor-management techniques to urban dispute settlement emerged. (FOSTER, 1973) This created the new role of Planner as Mediator to act as a "broker of conflict" so to speak. (Susskind, 1980) 
The creation of new planning roles and the increased diversity in the field is discussed and explained in the literature on planning theory. Thomas Galloway and Riad Mahayni offer their insight on this matter:

The development of urban planning as a field of study and as an area of policy application has been accompanied by diverse images to the scope, issues, concerns, and the type of activities with which the field is preoccupied. . This diversity is not new to the profession. There is reason to believe, however, that it has increased greatly with the past decade and that it is departing substantially from the conventional and popular definitions associated with the field in its earlier years.

(Galloway and Mahayni, 1977: 62)

They go on to explain that:

The diversity within the planning field raises a number of important questions concerning the present and future role of planning in urban policy making. This diversity has sprung from a number of alternative planning definitions and strategies.

(Galloway and Mahayni, 1977: 63)

As a matter of fact, these altemative planning definitions and strategies could possibly serve as normative theories for environmental mediation.

Consider the theories of Radical and Innovative Planning. The Radical Planning Theory rejects planning as it is traditionally perceived; that is, by the rational-comprehensive model. Stephen Grabow and Allan Heskin believe that "modernobjective planning," or rational-comprehensive planning, has elitist, centralizing, and change-resistant tendencies. (Grabow and Heskin, 1973: 108) They explain that these are principal reasons for rejecting "modern-objective" planning. 
Radical planning, by contrast, is a synthesis of rational action and spontaneity, whereby change is necessary and beneficial to society. Apparently it is not only society's goals that need changing, but also the very structure of rational action - the techniques of traditional planning - that need to be changed as well. The planner's role in radical planning is active - to serve as a, "radical agent of change." (Grabow and Heskin, 1973: 112)

The Theory of Innovative Planning is a bit more pragmatic than Radical Planning and offers an alternative to allocative planning. Allocative planning is traditional planning in the respect that it deals with the problem of resource limitation through planned allocation to achieve optimal use of a resource. Land use planning and budgetary planning are examples of this. Innovative planning, on the other hand, involves the mobilization of existing resources to create solutions and means to generate new resources. John Friedmann defines innovative planning as outlined below:

- Seeking to legitimize new social objectives or effect a major reordering in the priority of existing objectives.

- Concerned with translating general value propositions into new institutional arrangements and concrete action programs.

- Being more interested in the mobilization of resources than in their optimal use.

- Proposing to guide innovation processes through information feedback of the actual consequences of action.

(Friedmann, 1966: 194) 
Both radical and innovative planning concepts could possibly serve as normative theories for the use of mediation in planning. These theories also have application to environmental situations. Especially since the present institutional arrangement for environmental protection and management needs to be changed as evidenced by the proliferation of litigation and conflicts over environmental issues. Another reason these theories lend themselves to environmental situations is that the human environment is a limited resource which should be managed in an innovative rather than allocative way. The present environmental situation is such that new methods for its protection and management are needed critically. Hence, there is a definite need to move toward innovation in this field. 


\section{CHAPTER EIGHT: CONCLUSION}

The thesis of this paper is that mediation can provide the innovation needed to improve the effectiveness of the present environmental protection and management system. Proliferation of environmental conflicts is becoming an increasing threat to the system. With the currently unstable economic situation, costly litigation-resolved conflict is impractical. Something new is definitely needed and mediation offers a possible solution.

In lisht of the discussion presented throughout this paper, it is apparent that mediation in itself is not a panacea and cannot resolve all environmental conflict. Yet, it does offer an alternative to litigation in many conflict situations. Hence, mediation should be incorporated whenever possible in order to facilitate environmental decision-making. Taking a broader and longer-range future perspective the mediation process, philosophy, and fundamental concepts can be applied to create new institutional arrangements and methods for environmental protection and management.

In a recent lecture and seminar held at the University of Rhode Island by the Department of Community Planning, Larry Susskind outlined three evolutionary patterns of the role of government in society. This evolutionary trend shows where mediation would fit into the government environmental protection and management system. 
(1) Paternalistic Role of Government: In this role govermment is change resistant and not open to public input. It possesses an, "accept what we do or change us" attitude. Government clearly plays an allocative role with regards to environmental protection.

(2) Conflicting Role of Government: As citizens gained public participation rights and took on a more active role in government decision-making, conlicts increased. Conflict served to mobilize government into a more innovative environmental protection role. This is where the environmental movement currently is - in conflict with government. As Larry Jusskind said, "we have lots of number two."

(3) Co-Production:Role of Covernment; In this role government and interest groups have come to respect and accept one another, and to work together in order to co-produce a future which is desirable to all. This is the essence of planning. Public Interest + Government $=$ Joint Net Gain

As planners, we can innovatively plan for conflict and harness its energy in a creative way to move from number two to number three as described above. Mediation can provide the mechanism for innovation and mobilization which is necessary to implement this. Thus, parties involved in environmental disputes should be brought together, via mediation and its various related techniques, to co-produce and co-maintain new and more effective environmental protection methods and institutions. The incentive to implement and co-maintain the new arrangements is provided by the common goal of obtain- 
ing the mutually agreed upon environmental future. 
American Arbitration Association and Clark-NicGlennon Associates. Inc. "National Park Service Workshop on Mediation, Spring 1979." (Manual) Washington, D.C. : U.S. Department of the Interior and U.S. Council on Environmental Quality (Sponsors), 1979.

Brooks, Richard Oliver. "Municipal Environmental Ordinances, Volumes I and II." University of Rhode Island, Kingston, Rhode Island: Graduate Curriculum in Community Planning and Area Development and The Bureau of Government Research (Sponsors).

Carpenter, Susan L. and Kennedy, W.J.D. "Third Party Participation in Environmental Disputes: ROMCOE Case Studies." Paper presented at RESOLVE Conference, Reston, Virginia, 12 January 1978.

Carter, Jimmy. "The President's Message." In Environmental Quality, 1979: The Tenth Annual Report of the Council on Environmental Quality, pp. iii-v. By the U.S. Council on Environmental Quality. Washington, D.C.: U.S. Government Printing office, 1980.

Center for Ocean Management Studies. "Managing the Multiple Resources of the OCS: An Experiment in Facilitating Energy and Environmental Resource Decisions." (DRAFT) University of Rhode Island, Kingston, Rhode Island, 1980.

Chalmers, W. Ellison and Cormick, Gerald W., eds., Racial Conflict and Negotiations; Perspectives and First Case Studies. Ann Arbor, Michigan: Institute of Labor and Institutional Relations, 1971.

Chapin, F. Stuart, Jr. Urban Land Use Planning. Urbana, Illinois: University of Illinois Press, 1965.

Clark, Peter B. "Consensus Building: Mediating Energy, Environmental, and Economic Conflict." Environmental Comment, May 1977, pp. 9-11.

Clark-McGlennon Associates, Inc. Developing Methods for Environmental-Energy Dispute Settlement. (Final Report for Phase I) New York, N.Y.: the American Arbitration Association, 15 June 1978.

Coleman, James S. Community Conflict. Glencoe, Illinois: The Free Press, 1957. 
Commoner, Barry. The Closing Circle: Nature, Man and Technology. New York, N.Y.: Bantom Books, Inc., 1974.

Cormick, Gerald W. "Power, Strategy and the Process of Community Conflict: A Theoretical Framework." Ph.D. dissertation, University of Michigan, Ann Arbor, Michigan: University Microfilms, 1971.

Cormick, Gerald W. "Mediating Environmental Controversies: Perspectives and First Experience." Earth Law Journal 2 (1976): 215-224.

Cormick, Gerald W. and Patton, Leah K. "Environmental Mediation: Potentials and Limitations." Environmental Comment, Nay 1977, pp. 13-15.

Environmental Comment - Conflict Resolution Issue, Nay 1977. Washington, D.C.: ULI - Urban Land Institute, 1977.

Environmental Consensus, December 1978. Palo Alto, California: RESOLVE, Center for Environmental Conflict Resolution, 1978 .

Ibid, March 1979 (Vol. 2, No. 1)

Ibid, July 1979 (Vol. 2, No. 2)

Ibid, Winter 1980

Foster, Howard H., Jr. "Urban Disputes, Mediation and the Planning Profession." Paper presented at Confer - In 73. University of Rhode Island, Kingston, Rhode Island, 1973.

Frederiksen, Robert $C$. "Environmental drive going down the drain, marine experts told." Providence Journal. 24 June 1980, sec. 1, p. A-3.

Friedmann, John. "Planning As Innovation: The Chilean Case." Journal of the American Institute of Planners 32 (July 1966): 194-203.

Friendly, David T. with Reese, Michael and Malamud, Phyllis. "Environmental Mediators." Newsweek, 17 March 1980,. p. 79 .

Galloway, Thomas D. and Mahayni, Riad G. "Planning Theory in Retrospect: The Process of Paradigm Change." Journal of the American Institute of Planners 43 (January 1977): $62-71$.

Grabow, John and Heskin, Allan. "Foundations for a Radical Concept of Planning." Journal of the American Institute of Planners 39 (Narch 1973): 106-114.

Haefele, Edwin T. Representative Government and Environmental Management. Baltimore, Maryland: The Johns Hopkins University Press, 1973. 
Hariss, C. Lowell, Ed. The Good Earth of America - Planning Uur Land Use. Englewood Cliffs, New Jersey: PrenticeHall, Inc., 1974.

Healy, Robert G. and Rosenberg, John S. Land Use and the States. Baltimore, Maryland: The Johns Hopkins University Press, 1979.

Heikoff, Joseph M. Coastal Resources Nanagement: Institutions and Programs. Ann Arbor, Michigan: Ann Arbor Science Publishers, Inc., 1977.

Hodgson, J.D. "Preface." In Techniques of Mediation in Labor Disputes, pp. ix-x. By Walter A. Maggiolo. Dobbs Ferry, New York: Oceana Publications, Inc., 1971.

Hoffman, Eileen B. Resolving Labor-Management Disputes: A Nine Country Comparison. New York, N.Y.: The Conference Board, Inc., 1973.

Hufstedler, Shirley M. "What the Courts Cannot Do." Washington Post, I January 1978, sec. 2, p. B-8.

Ketchum, Bostwick H., ed. The Water's Edge: Critical Problems of the Coastal Zone. Cambridge, Viassachusetts: The Ni.I.T. Press, 1972.

Lake, Laura $M$. "Unifying the Concept of Third-Party Intervention in Environmental Disputes." Environmental Comment, Nay 1977, pp. 6-9.

Like, Irving. "Of The National Environmental Policy Act." In Environmental Legislation: A Sourcebook, pp. vixiv. Edited by Mary Robinson Sive. New York, N.Y.: Praeger Publishers, Inc., 1976.

Likert, Rensis and Likert, Jane Gibson. New Ways of Mianaging Conflict. New York, N.Y.: McGraw Hill, 1976.

Maggiolo, Walter A. Techniques of Mediation in Labor Disputes. Dobbs Ferry, New York: Oceana Publications, Inc., 1971.

O'Connor, David. "Environmental Mediation: The State-ofthe-Art." EIA Review, October 1978.

RESOLVE, Center for Environmental Conflict Resolution, ed. Environmental Mediation: An Effective Alternative? Palo Alto, California: RESOLVE, 1978.

Rivkin, Malcolm D. Negotiated Development: A Breakthrough In Environmental Controversies. Washington, D.C.: The Conservation Foundation, 1977.

Shaw, Bill. Environmental Law: Feople, Pollution, and Land Use. St. Paul, Minnesota: West Publishing Co., 1976. 
Simkin, William E. Mediation and the Dynamics of Collective Bargaining. Washington, D.C.: The Bureau of National Affairs, Inc., 1971.

Sive, Nary Robinson, ed. Environmental Legislation: A Sourcebook. New York, N.Y.: Praeger Publishers, Inc., 1976.

Susskind, Lawrence E. The Importance of Citizen Participation and Consensus Building in the Land Use Planning Process. Paper prepared for the Lincoln Institute Land Use Symposium, Cambridge, Massachusetts, 27-29 October 1977. Revised January 1978. Cambridge, Massachusetts: M.I.T., 1978 .

Susskind, Lawrence E. Richardson, James R.; and Hildebrand, Kathryn J. Resolving Environmental Disputes: Approaches to Intervention, Negotiation, and Conflict Resolution. Cambridge, Massachusetts: Environmental Impact Assessment Project, Laboratory of Architecture and Planning. M.I.T., June 1978.

Susskind, Jawrence $E$. Lecture and seminar on mediation conducted at the University of Rhode Island by the Graduate Curriculum in Community Planning and Area Development, 1 May 1980.

U.S. Council on Environmental Quality. Environmental Quality, 1979: The Tenth Annual Report of the Council on Environmental Quality. Washington, D.C.: U.S. Government Printing Office, 1980.

Vaughn, Barbara and Hunter, Lori. Selected Readings In Environmental Conflict Nanagement. Palo Alto, California: RESOLVE.

Warren, Charles. "The Hopeful Future of Mediation: Resolving Environmental Disputes Outside the Courts." In Environmental Mediation: An Effective Alternative?, pp. 9-16. Edited by RESOLVE. Palo Alto, California: Resolve, 1978. 